\title{
Singularities of Perspective in Spain: The 'Other Treatises' on Perspective and their Importance within the European Context
}

\author{
José María Gentil Baldrich ${ }^{1}$ Andrés Martín-Pastor ${ }^{2}$ (D)
}

Published online: 28 July 2016

(C) Kim Williams Books, Turin 2016

\begin{abstract}
Regarding drawing perspective, Spanish tradition has hidden singularities that greatly distinguish it from other European traditions. Spanish tradition, however, simultaneously nurtures ideas from these traditions, such as those of Italy and France, creating multiple variations and novelties. This study presents a brief journey through the lesser-known exempla, which are lesser studied in the scientific community. The study focuses on the 'angular perspective' by architect Hernán Ruiz the Younger (el Joven), the innovative construction of figures in perspective by the carpenter Antonio de Torreblanca and the singular contributions to the anonymous manuscript Artes Exçelençias dela Perspectiba. All three studies are similar in that they feature novel and heterodox premises within the general theory.
\end{abstract}

Keywords Historical treatise $\cdot$ Manuals $\cdot$ Perspective $\cdot$ Geometric construction $\cdot$ Representation of architecture $\cdot$ Polyhedra

Andrés Martín-Pastor

archiamp@us.es

José María Gentil Baldrich

jmgentil@us.es

1 Department of Architectural Graphic Expression, Universidad de Sevilla, ETSA, Av/Reina Mercedes, 2, 41012 Seville, Spain

2 Department of Graphic Engineering, Universidad de Sevilla, ETSIE, IUACC. Instituto Universitario de Arquitectura y Ciencias de la Construcción, Av/Reina Mercedes, 4 A, 41012 Seville, Spain 


\section{Introduction: Perspective Manuscripts in the Spanish Tradition}

As it is commonly known, the study of perspective is a multidisciplinary approach comprising a number of individual yet interrelated areas of knowledge. Despite essentially being an issue of language and communication, its expression is also a question of ideology. The study of perspective is also, in its purest form, an instrumental issue; it is both geometric and technical which enables its use and application (Gentil Baldrich 2012b).

Accordingly, we cannot speak of a single tradition on perspective in Spain since it has evolved over the centuries. Its grammar has been constructed from different axioms and even fashions. Thus we shall speak of a unique 'angular perspective' in Spain, inspired by the scientific teachings of Euclid and crossed with an Italianized vision of perspective that eventually dominated artistic circles and guilds. This was made possible by direct contact with Italian and Flemish artists in the cultural melting pot that was the works of Phillip II's Escorial palace in Madrid. Also key was the arrival of prestigious treatises, full of innovative and impressive illustrations, such as those of Vignola and Danti (1583) and Sirigatti (1596).

The eventual use of perspective construction based on the intersection of the visual pyramid with the picture plane rather than more abstract methods must also be analyzed within an evolutionary logic. It is the result of the advantages of this particular method in saving time and effort over more confusing and complex methods. The methodological evolutions that followed, from the 'seconda regola' by Vignola and Danti, the 'punctus contingentia' by Marolois (1633), or the perspectograph, up to the camera obscura and finally the photograph, also seek 'the easiest way', as previously expressed by Albrecht Dürer.

However, we should bear in mind that, besides painters, representing space on a plane is also an issue for architects, carpenters and engineers (Burucúa 19891990-1991). Any builder in a complex production system going beyond medieval guild logic needs a method to define and control objects in space starting from a projection plane. In accordance with this they must measure and define all the geometric parts, create templates, calculate expenses, and finally visualize the work before its construction. In this way the evolution reflected in the perspective treatises reveal the true manuals of graphic science in each historical period including the geometric corpus, and theory of polyhedral and projection issues. These form the basis from which all modern systems of representation have been defined, from Monge (1797) to the arrival of CAD technology.

In Spain there are key examples of this trend, outside of pictorial tradition, which deal with the graphical problems within construction crafts. These manuscripts had a private and professional use but in other cases were conceived as real treatises, even prepared for editing but then never published. Within this group of manuscripts the following have been studied: Ruiz (1560), ${ }^{1}$ Antonio de Torreblanca

\footnotetext{
1 The manuscript was studied and edited by Navascués Palacio (1974), then by Alfonso Jiménez Martín (AA.VV. 1998). Regarding the section on perspective, previous research was done by Cabezas-Gelabert (1984), Gentil Baldrich (1998), and Gentil Baldrich (2012b: 97-107).
} 
(1600, 1616-1617), ${ }^{2}$ Salvador Muñoz (1642), Felipe Lázaro de Goiti (1643), Luis Carduchi (1650), Simón García (1681), Fray Andrés de San Miguel (1652), Juan Andrés Ricci de Guevara (1659), and the magnificent, also anonymous manuscript Artes Exçelençias dela Perspectiba (Anonymous 1688). ${ }^{3}$

Three unpublished manuscripts have been selected from this group; they are of particular interest due to their little known contributions to the field of perspective: The manuscripts of Hernán Ruiz the Younger and Antonio de Torreblanca, as well as the anonymous work entitled: Artes Exçelençias dela Perspectiba. The reason for this selection is that they share a common ground; the three manuscripts contain postulates that are complementary or divergent from the theories generally accepted in Europe at the time. These new postulates are of great interest as they tackle obscure or rejected geometry practices which have stayed in the dark until now. The fact that conic perspective eventually reached a geometric corpus that was widely accepted did not prevent individual research into lesser studied heterodox issues from appearing. This paper outlines the cases found in the Spanish sphere.

\section{An Angular Perspective in Sixteenth Century Spain}

The first case shows the survival of the axioms of angular projection collected in the work of Euclid, ${ }^{4}$ which remained constant in all Greek authors dealing with optics such as Geminus, Proclus, and Ptolemy. These axioms were studied and discussed by other scholars in the Middle Ages-Al Kindi, Bacon, Peckham, Alhazen, and Vitelius - until the elaboration of a theory of vision known as perspectiva naturalis. This theory of vision contrasts with the perspectiva artificialis that would later be applied to painting and graphic expression of space. In certain circles this precept was preserved due to the prestige that its ancient origin provided. This was claimed by Juan de Herrera, the greatest Spanish architect of his period, director of architecture of El Escorial and first director of the Academy of Mathematics. ${ }^{5}$ In his work La Institución de la Academia Real de Matemáticas, Herrera recommends perspective scholars read "the first six books by Euclid, also his eleventh and twelfth book; the perspective and specularia by Euclid and Ptolemy, as well as the

\footnotetext{
2 The first study which was novel in the Spanish context was brought to light by Prof. Carmen GonzálezRomán (2007). The second manuscript was researched by Navarro de Zuvillaga (1989).

3 First study approach to the manuscript: Gentil Baldrich and Martín-Pastor (2006). A more complex research study by Martín-Pastor (2009). There is a facsimile edition of the treaty with analysis and transcriptions by Martín-Pastor et al. (2010). Gentil Baldrich (2012a) provided a chronicle on the eventful whereabouts of the manuscript up to its facsimile reproduction. A study on the architectural representation of the treaty can be found by Martín-Pastor and Granado-Castro (2015), and a first study on the manuscript polyhedra was done by Gentil Baldrich and Martín-Pastor (2015).

${ }^{4}$ With respect to perspective, the reference is to Euclid's 8th theorem: the apparent difference between two equal dimensions approached from unequal distances is determined by the relation of the corresponding visual angles. Time held firmly, and without exception, the assumption that visual dimensions are not determined by the distance between the eye and the object, but rather by the measure of the visual angle (Panofsky 1927: 19).

5 The Royal Academy of Mathematics was an institution established by Phillip II in 1582 on Juan de Herrera's initiative.
} 
legacy of these theories in the works of Alhazen and Vitellion" (Herrera 1584: 14). At this time, Euclid's Elements had already been translated into Spanish by Zamorano (1576), and precisely one year after the publication of Herrera's work, another text by Euclid was translated by Ambrosio Ondériz (1585) entitled Perspectiva y Especularia. In this way, in his important work, Commentariorum in astrolabium, Juan de Rojas Sarmiento (1551) illustrates the way to measure buildings using his instrument, which provided him angular readings (Fig. 1). This book was undoubtedly in circulation in Seville, whose university currently conserves three copies. It also awoke the interest of architects such as Juan Bautista de Monegro, who had a copy in his library.

For this very reason, there is a marked preference towards angular perspective in Spain, which is the very theory found in the manuscript written by Hernán Ruiz the Younger (1560) and presented in literature which is not widely disseminated (Gentil Baldrich 1998). His manuscript-exact date unknown but developed during his lifetime - contains a compilation of what may be the concerns of the Renaissance architect, including a crucial part on conical perspective, which is discussed in this paper.

Some studies emphasize the correlation of the manuscript perspective images with the second book by Serlio (1545) which deals with this subject (Navascués Palacio 1974: 19-22). However, there are other architectonic representations that use an entirely different procedure, outlined below. For this purpose, it is useful to graphically reproduce the procedure used by Hernán Ruiz using some of his most significant drawings. Some of the geometric constructions portrayed in a significant drawing in the manuscript (Figs. 2, 3) will be reproduced here. The illustration shows a double parallelepipedic space flanked by two side buttresses-not to the full height of the construction - these are joined using a simple masonry bond. This drawing, though simple, problematizes other similar spaces. Its double height allows

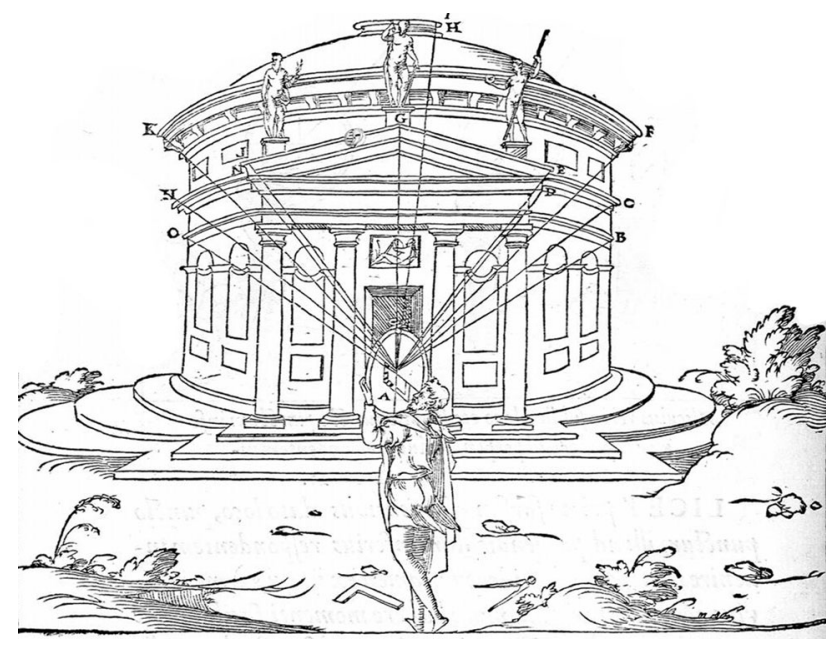

Fig. 1 Use of mathematical instrument to measure architecture by angular reading. (Rojas Sarmiento 1551: 196) 
Fig. 2 Graphic composition illustrating angular procedure in perspective construction (Ruiz 1560: fol. 86)

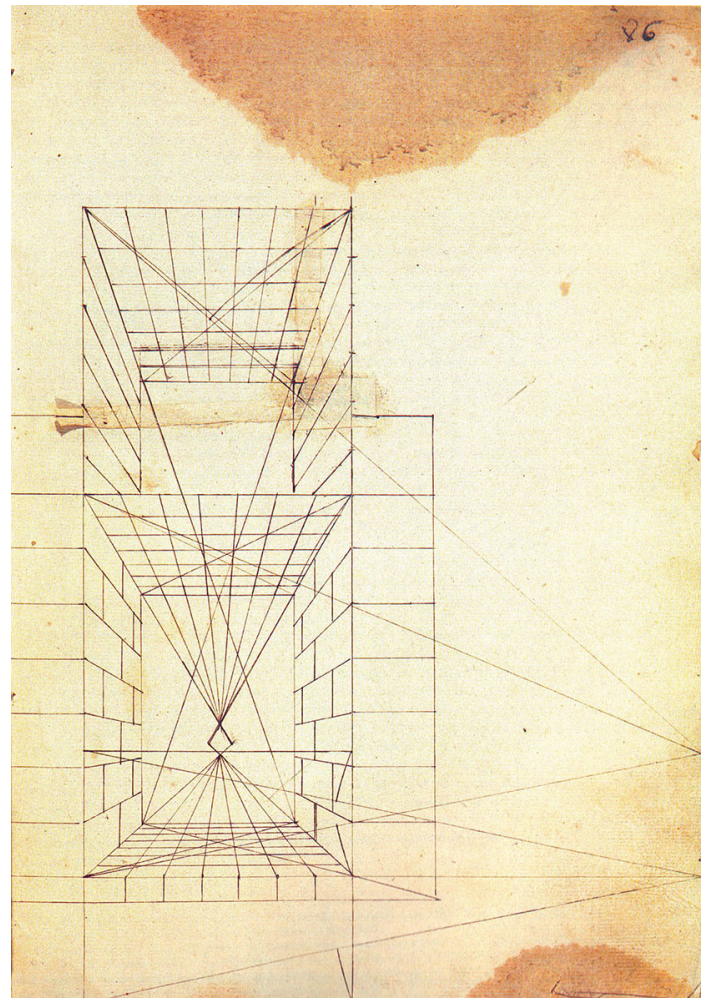

the observation of interesting geometric issues, as all the lines are easy to follow due to their schematism.

We can understand Hernán Ruiz's diagram as a superposition of a floor and a section. In the graphic transcription (Fig. 3), the floor is defined by the square A-BC-D and the section by points F-G-H-I-J-K. The geometric procedure adopted appears to operate in two different planes, that of the floor and that of the section (Fig. 4). In both, the depth is determined by the springing line of this arch, which spans this depth. The origin of this arch is found at the intersection of the picture plane, which in this case coincides with the plane of front elevation.

From the point of view of $\mathrm{V}$, the floor projection, we outline the angle spanning segment B-C. With an arch from centre V, we find the springing line B-c', which is transported to the plane of the square to define segment B-c. Similarly, we find its symmetrical pair A-d, determining the lateral foreshortening of the depth in perspective. In the plane of the section starting from the top, we draw the angle from V' for segment I-J. With an arch with the circumference around centre V', we mark the springing line i'-J, which is transported with a rotation around centre $\mathrm{J}$, to its position in the picture plane i-J. In the highest part of the section (Fig. 4) we see segment $\mathrm{i}-\mathrm{J}$ is shorter than that which would have been produced using Leon Battista Alberti's procedure of intersection in the visual pyramid with the picture plane. 


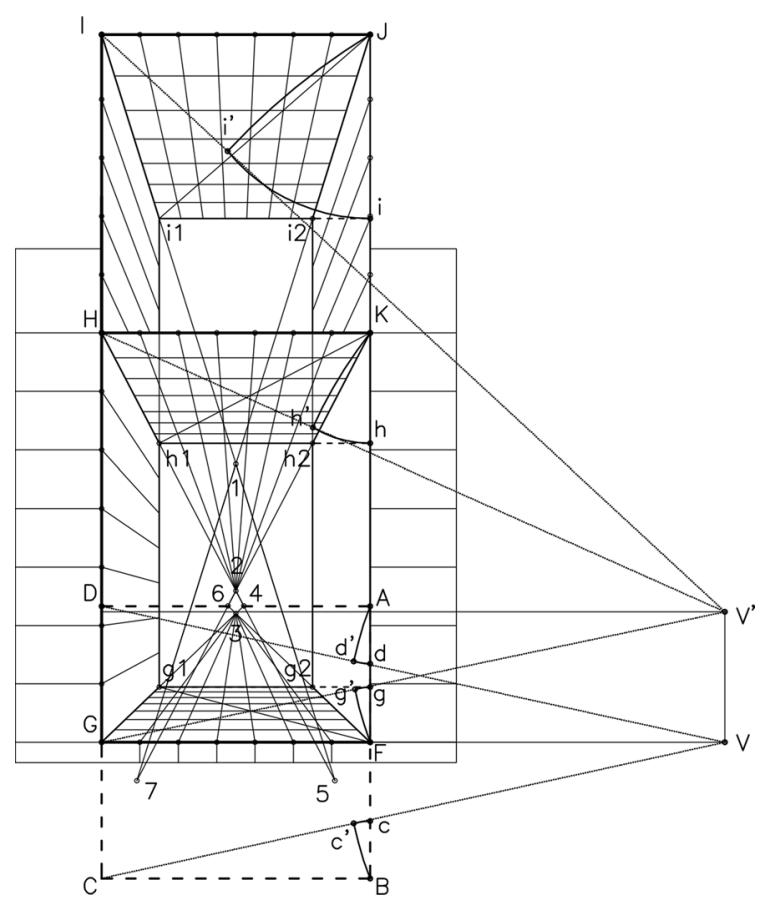

Fig. 3 Reconstruction of Hernan Ruiz II's angular procedure elaborated by authors

The auxiliary lines drawn from i-J and c-B, d-A, determine positions i1 and i2 of the perspective. The intersection of segment I-i1 with J-i2 determines point 1 , the vanishing point of the set of lines running perpendicular to the plane of the square, which are contained within this upper horizontal plane.

In the same way we find segment $\mathrm{h}-\mathrm{K}$, which, using auxiliary lines, defines the perspective points $\mathrm{h} 1$ and $\mathrm{h} 2$ as well as the vanishing point 2 for the middle horizontal wall section. Likewise, the points of the lower floor of g1 and g2 are determined and vanish at 3 . The perpendicular lines in the left-hand vertical wall sections (lower and upper) vanish at 4 and 5 respectively. Points 6 and 7 are where the lines in the right-hand wall sections vanish. We can assume that the joint vanishing of the upper verticals at point 1 is a mistake, as observed in the manuscript (Fig. 2). We propose the correct vanishing points of 5 and 7, according to the applied logic. Finally, we have a system made up of seven vanishing points (one for each wall section), with a rhomboid shape in the centre part.

On folio 56 there is an illustration of a portico of three spans and an upper central body, which is, without a doubt, the most important construction in perspective in the manuscript (Fig. 5). After carrying out an analysis of the different vanishing points, we can confirm the existence of a sketch showing the main proportions of the composition according to angular perspective. Nevertheless, we must also mention that all the architectonic details vanish in a single central point, perhaps used to simplify the illustration. 


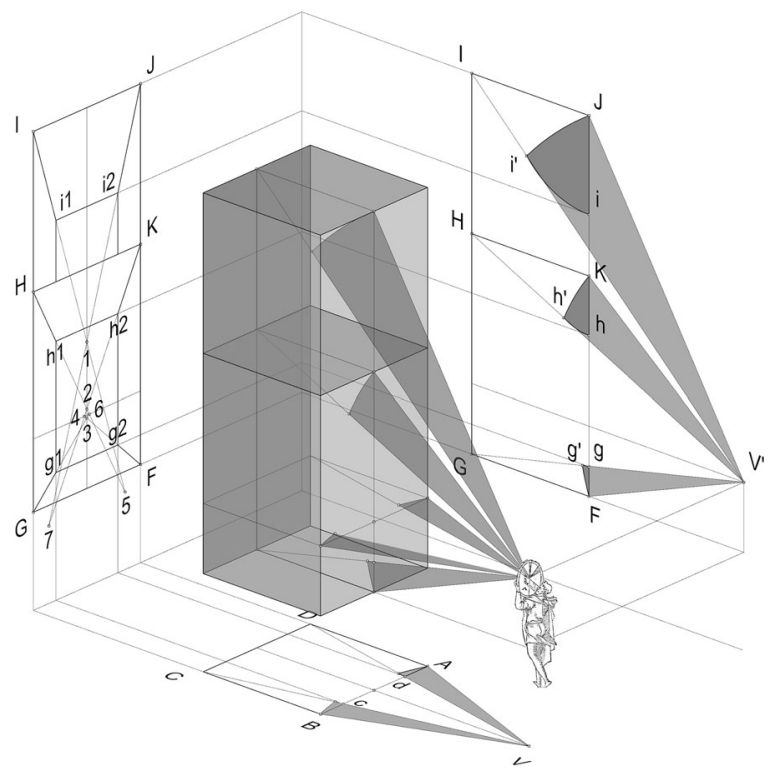

Fig. 4 3D scheme of Hernan Ruiz II's angular procedure elaborated by authors

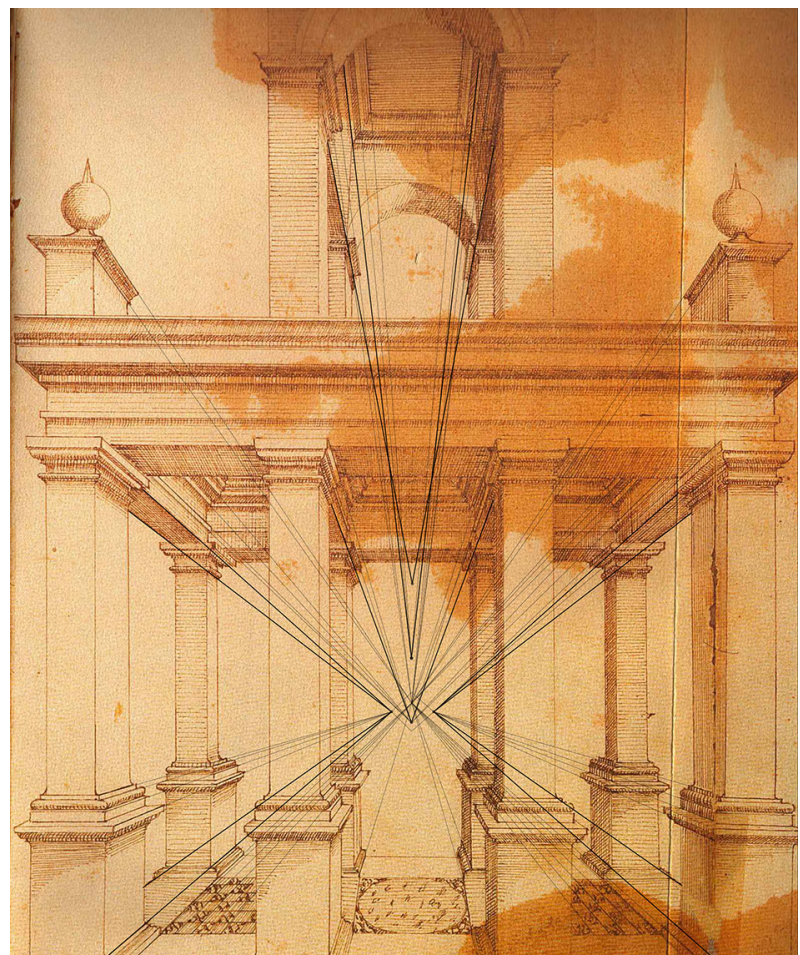

Fig. 5 Three-bayed portico designed by the angular procedure (Ruiz 1560: fol. 56) 


\section{The Innovative Graphic Procedure of Perspective Representation by Antonio de Torreblanca}

The second case is the analysis of another unsolved question within the artistic perspective: the mandatory bifocal terms of vision versus the single point of view of the conic projection. This subject could be traced back to the origins of perspective codification and arises in the form of procedure when considering a graphic system dominated by two points of view instead of a single one. In Spain, this question is studied by Antonio de Torreblanca in one of his treatises as the starting point for a procedure that he calls Regla novedosa (new rule). ${ }^{6}$

In the analysis of Torreblanca's works we are inclined to agree with Navarro de Zuvillaga (1989) that his true sources are in fact Serlio (1545), Barbaro (1569), Vignola and Danti (1583), and Sirigatti (1596). These Italian masters were the common referents in Spain during the seventeenth century. Torreblanca primarily uses Vignola's seconda regola; taking advantage of the structural facility permitted by the distance points with respect to the prima regola, which corresponds to the costruzione legittima by Leon Battista Alberti.

Torreblanca's predilection for Vignola and Danti's treatise can also be observed in the use of 'particular points', points at infinity where any group of lines vanishes (Fig. 6). These points - subsequently calculated to the floor plan perspective projection-are a first approximation of what Burbon del Monte (1600), Lib. II, 3) eventually defined as puncta concursus.

But the most interesting issue regarding innovation-or heterodox reinterpretation of previous procedures-is Torreblanca's novel Regla (rule) of perspective representation, discussed in his second treatise:

Rule worthy of merit by its own excellence, and known by few, I dare not say by none as this would be too bold, but still I do not know of anyone who has studied this subject or written about it, and as such, I doubt anyone has mastered it in this very fashion, as the present work is the result of my effort alone. $^{7}$ (Torreblanca 1616-1617: fols. 59-59v).

\section{Study of the Novel Regla by Antonio de Torreblanca}

This method of perspective representation is a variation on the bifocal model. The procedure is found in previous authors before unified perspective, and it is also previously codified in the work of Pomponio Gaurico (1504). According to Chastel and Klein in their analysis of this author, this system is derived from a very old

\footnotetext{
6 The first version, Los siete Tratados de la perespectiva pratica...(c.1600), and a later, more complete version entitled, Los dos libros de geometría y perespectiva pratica...(1616-1617). The new rule appears in the second.

7 Translated from original quotation: “...digo que no ha venido a mi noticia que de nadie aya sido escripta ni sabida... dudo la sepan de la misma manera aunque diferentemente podrá ser se encuentren los pensamientos porque es puro trabajo mío." (Torreblanca 1616-1617: fols 59r-59v).
} 


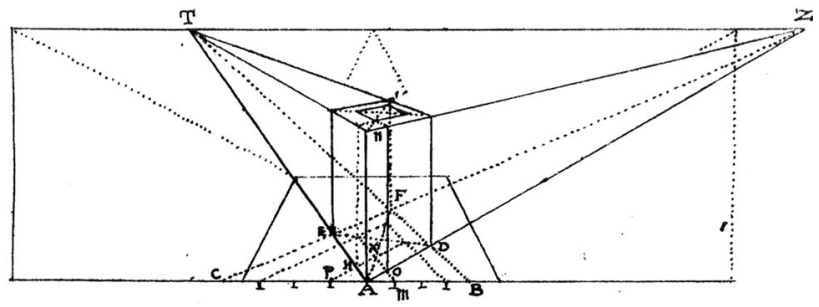

Fig. 6 Use of the 'particular points' in Torreblanca's treaty (Torreblanca 1616-1617: fol. 21v)

procedure known as 'bifocal', which apparently may help to explain the system propounded by Torreblanca:

Tracing in the horizon two opposed points, on the sides of the image, or outside; the base is divided into a number of perfectly equal sections and each point is linked with all those divisions, obtaining a system of two oblique, crosswise pyramids [...] From this point it is easy to accomplish a net of squares parallel to the picture plane. (Chastel and Klein 1989: 199).

Thus, it may be deduced that: 1 . Diagonals are projected prior to orthogonals; 2 . The central vanishing point is not determined, while the distance point is taken as initial; 3. A finitix plani or final picture plane is located on the horizon, limiting the number of transversals to half of the orthogonals, as Fig. 7 shows.

According to Chastel and Klein, the 'bifocal method' may be improved, for example by superimposing the orthogonals pyramid onto the side pyramid of the bifocal system, as proposed by Viator (1505). In the same way, the procedure of the 'distance point' could have been an evolution of the artisans' bifocal method after being compounded with the procedure proposed by Alberti. Even if there was some crossover between these two methods and the work of the Italian-as it may be now assumed-their long-term interrelation was not confirmed until the sixteenth century (Chastel and Klein 1989: 200).

In Torreblanca's work this relation between the workshop procedures related to the 'bifocal' method and Vignola's seconda regola (Fig. 7) is clear.

In Fig. 8, a sketch to demonstrate his Regla in the next folio, Torreblanca uses control points $o, n, k, m$, representing the true length of segments of the crossover with line $A-B$, hereby applying the 'distance points' method. In turn, line $A-B$ defines the picture plane. One can see the same sequence of points labeled with capital letters $O, N, K, M$, arranged in the upper line which defines the intersection of this other plane with the picture plane. If a series of auxiliary vertical lines were drawn-which Torreblanca didn't do-the correspondence between the two groups of points could be verified. Furthermore, the rectangle that circumscribes the cross in both cases touches the picture plane with the same letter $K$. This point will be especially significant in the following procedure.

Figure 9 shows the cross in a different perspective. The change is due to both the 'geometrical' and the 'horizontal planes' (also called 'ground plane' and 'the horizon') having been rotated $33^{\circ}$. 


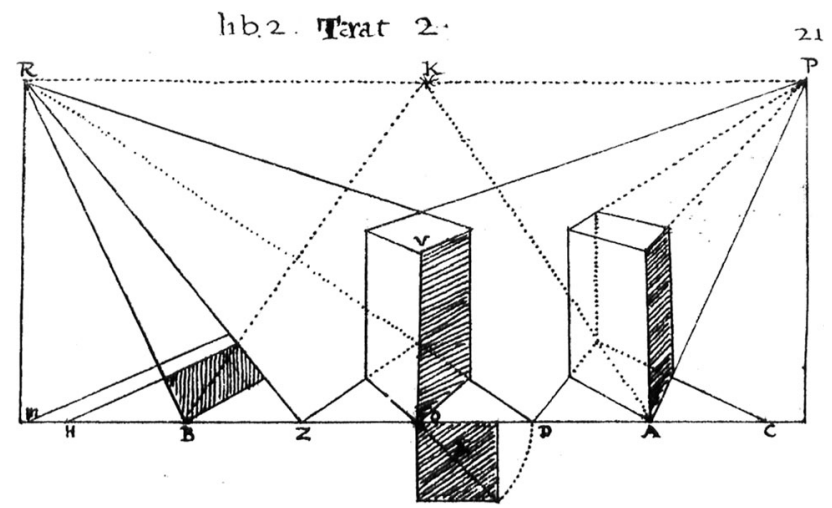

Fig. 7 Relation between bifocal method and Vignola's seconda regola (Torreblanca 1616-1617: fol. 21)

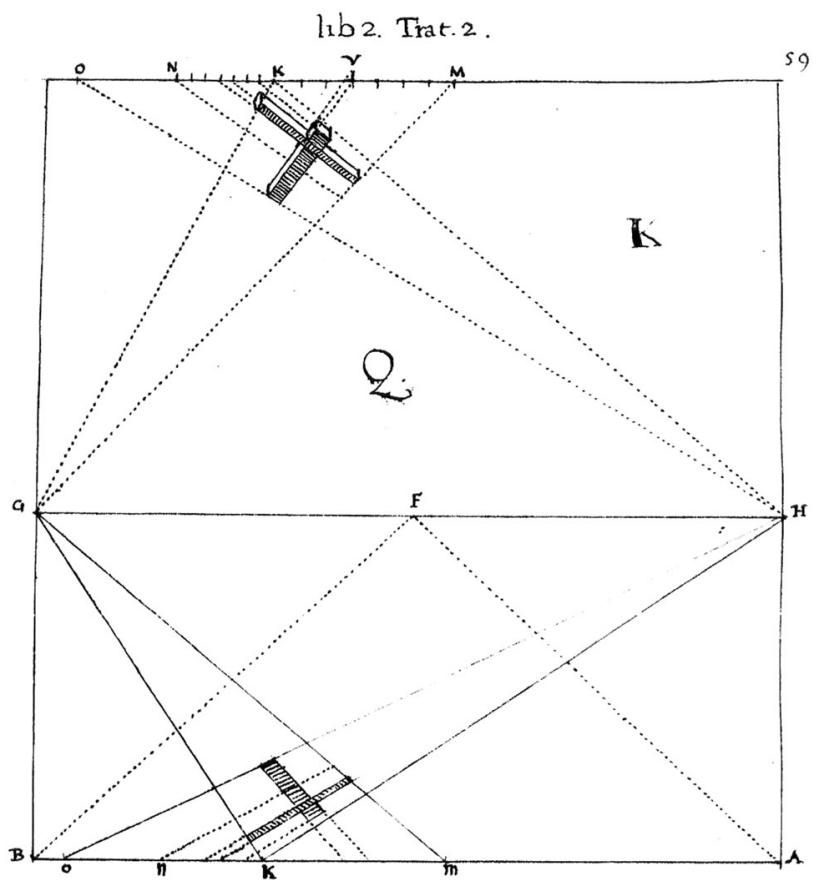

Fig. 8 Representation of crosses contained in parallel planes to the geometrical one (Torreblanca 1616-1617: fol. 59)

It is important to note that the line representing the intersection of the geometrical plane and the picture plane is still termed $A-B$ as in the previous example. The upper parallel line defines its corresponding parallel plane (not called 'the horizon' as it is not the same as the visual experience horizon). In the context of mathematics the rule previously described in Fig. 8 will still be valid in Fig. 9. The procedure could easily be explained if we consider that the orientation has rotated 
$33^{\circ}$ (Fig. 10) to carry out the procedure previously described in the case of the top cross. In this same illustration we can see that the point of view is not represented, exactly as the bifocal system postulates.

By means of his Regla Torreblanca aims to generalize a well-known procedure not only to control the perspective of objects contained in planes parallel to the geometrical plane, but also for figures contained in any plane perpendicular to the picture plane (Figs. 11, 12). His rule could be understood as a generalization of the bifocal system based on the distance points. This enables one to arrange perspective projections of figures contained in any plane perpendicular to the picture plane.

\section{The Unpublished Manuscript Artes Exçelençias dela Perspectiba}

The third case analyzed in this paper is a contribution from one of the four books contained in the anonymous manuscript treatise, Artes Exçelençias dela Perspectiba. This is kept in the private Archives at the Casa Medina Sidonia Foundation in

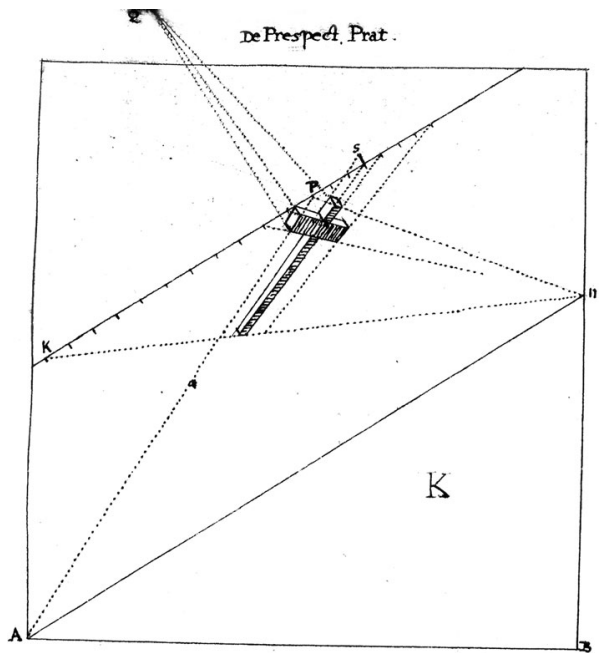

Fig. 9 Regla (rule) to represent the perspective of objects contained in the frontal plane to the pictureplane. (Torreblanca 1616-1617: fol. 59v)

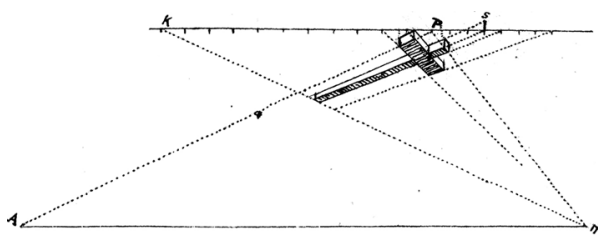

Fig. 10 Correspondence of the previous procedure, rotated, to the representation of a figure in a plane

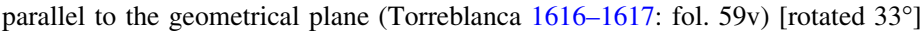




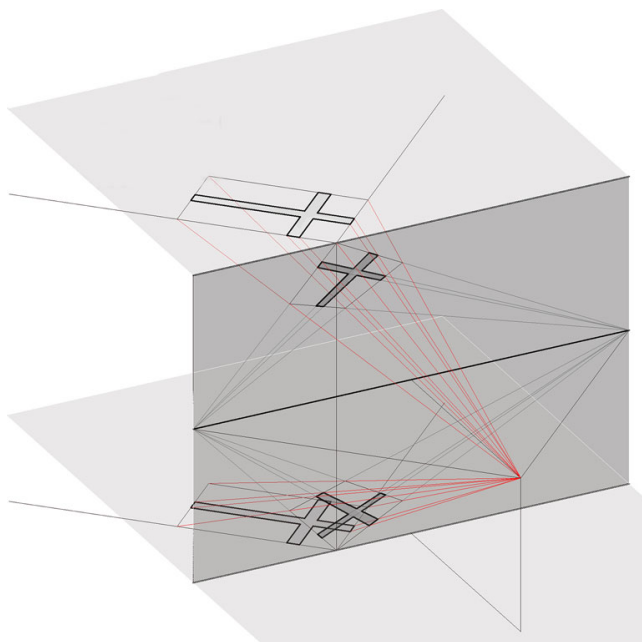

Fig. 11 Graphic illustration of crosses represented in parallel planes to geometrical plane. Elaborated by authors

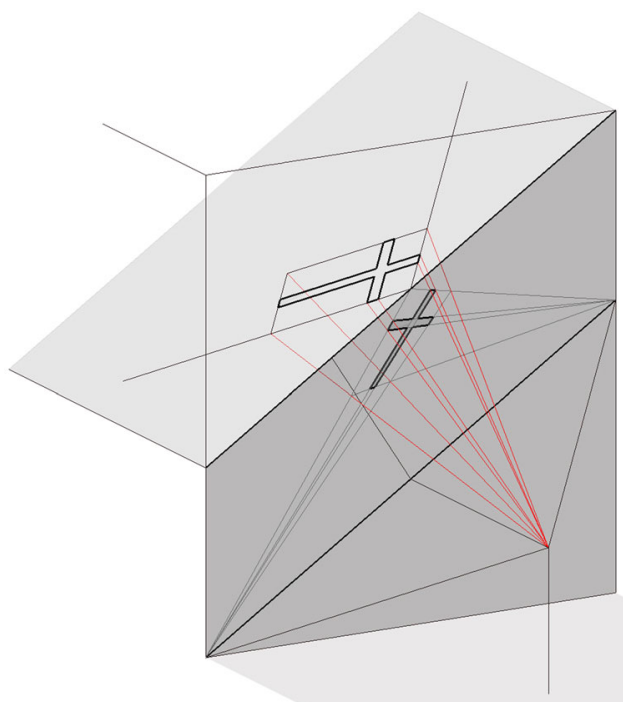

Fig. 12 Reconstruction elaborated by authors 
Sanlúcar de Barrameda, Cádiz, Spain. Unlike the cases previously mentioned this text neither aims to reformulate angular axioms nor to reconsider ambiguous procedures in the canonical trend. ${ }^{8}$ Its contribution focuses on a particular model of perspective restitution that endows bodies with a geometric dimension starting from just one image (a perspective). Thus, the author accomplished an amazing interpretation of complex illustrations dating from the period.

The study, Artes Exçelençias dela Perspectiba, is a unique piece in Spanish treatise tradition that contributes to the evolution and singularity in the development of perspective studies during the seventeenth century (Martín-Pastor 2009). The unfinished manuscript comprises four books; the first two are complete and deal with theoretical and abstract aspects of perspective representation and its practical development in architecture (Martín-Pastor and Granado-Castro 2015). The third book studies the graphic construction of quadratures and architectural trompe-l'œil creations. Finally, the fourth book, which contains the contribution discussed in this paper, focuses on the analysis of the polyhedra and the problem of restitution.

\section{The Interpretation of Jamnitzer's Polyhedra}

As the author proudly declares in the introduction to the fourth book, it is a novel approach to the study of solid regular bodies. Peculiarly, a polyhedra analysis also found in Perspectiva Corporium Regularuim by Jamnitzer (1568) goes unmentioned by the author (Fig. 13). It is precisely this omission, quite rare given the nature of the work, which leads us to think that the author probably studied an anonymous copy of Jamnitzer's work entitled Sintagma, which was in circulation in that period.

As no one before has written about this subject, or at least not the scholars I have met. Most of the brightest ones do not dare to expound the method of representation for regular solid bodies which provide such curious speculations. Through my work and dedication I have obtained a reward that many others did not achieve because of their neglectfulness, and my happiness is the result of their laziness. ${ }^{9}$ (Anonymous 1688: fol. 57v).

The reinterpretation of the polyhedra illustrations found in Sintagma is an innovative approach without precedent at the time. The author's contribution consists in devising a system that firstly allows the deducing of metric or proportional information simply from perspective illustrations. Also it would allow the construction of polyhedra with pedestals, truncations, bevels, cavities, etc., starting from an exploratory system of base proportions (Fig. 14).

\footnotetext{
${ }^{8}$ Worthy of note is the presence of Marolois (1633), Niceron (1646), Dubreuil (1642), Hondius (1625), or Desargues (1648), famous French and North European authors widely known in the circles of Paris and the Netherlands, but of little impact in Spain.

9 Translated from original quotation: "Como ninguno de quantos hasta aqui han escrito sobre la materia que tratamos ò por lo menos ninguno de los que hasta aqui he visto siendo la mayor parte de los que mejor se han aplicado no exponen el methodo a representar los cuerpos solidos regulares en que tan curiosas especulaciones se pueden hacer yo he solicitado a costa de mi trauajo y aplicación, la gloria que otros no han obtenido ò por su negligencia y mi buena dicha u por su inuencible pereça..." (Anonymous 1688: fol. $57 v)$.
} 
Fig. 13 Star-shaped polyhedron on pedestal (Jamnitzer 1568: A E III 2)

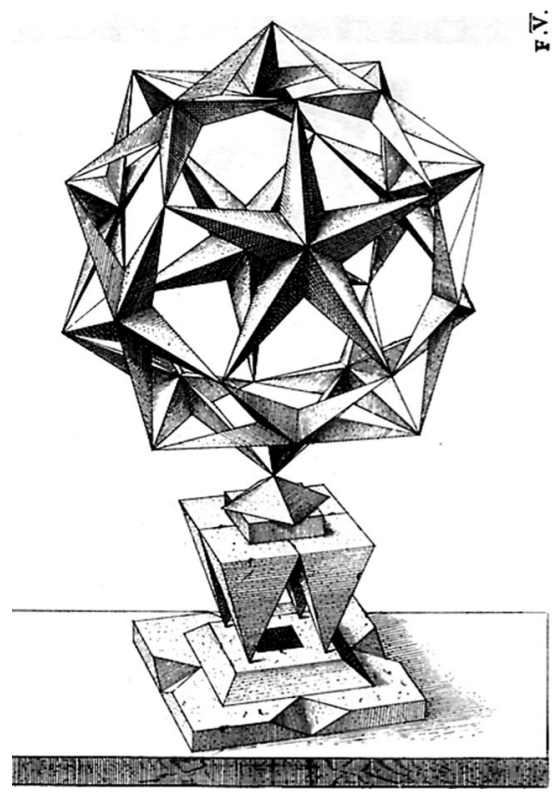

The geometric study performed includes the reconstruction of polyhedra according to the author's explanations (Fig. 15). This revealed an evident coherence between the geometric rigor and the literary explanation as well as a number of other singularities (Martín-Pastor and 2009). One of these singularities is the personal graphic construction of what the author calls 'formularis de las alturas' (figured in the upper part of Figs. 16, 17). This is an elevation construction of enormous interest that results from the elements arranged in the floor plane and was previously included in a study by Niceron (1646). It may be observed that the tridimensional aspects and therefore the idea of space always result from the floor projection and the metric relations from the floor projections.

This hypothesis is based on the existence of a generating order across all graphic construction. On the one hand there is a strict order in the perspective construction. On the other hand there is an absolute order in the system of proportions or modules that coordinates the formal apparatus of representation specifically to justify the creation of fanciful pedestals under the polyhedra (as observable in the lower part of Figs. 14, 16). Clearly, as in the case of the architectonical orders approached in his previous book, the dimensional control of a form should obey a very specific law. A law that in this case will be codified in the form of a graphic procedure which must be formulated as a relation of points and lines in the projection plane (Figs. 14, 16).

The restitution procedure work of the bodies found in Sintagma is a subject that our author does not mention. There is not one explanation in the whole treatise about how such complex tridimensional geometry is metrically deduced. Also, it also remains unexplained how the author can find the specific position of the point of view with respect to the object and the picture plane. Indeed, when comparing the 
Fig. 14 Reinterpretation of the star polyhedron construction by Jamnitzer in the anonymous manuscript (1688: fol. 72r)

Fig. 15 Graphic transcription elaborated by authors
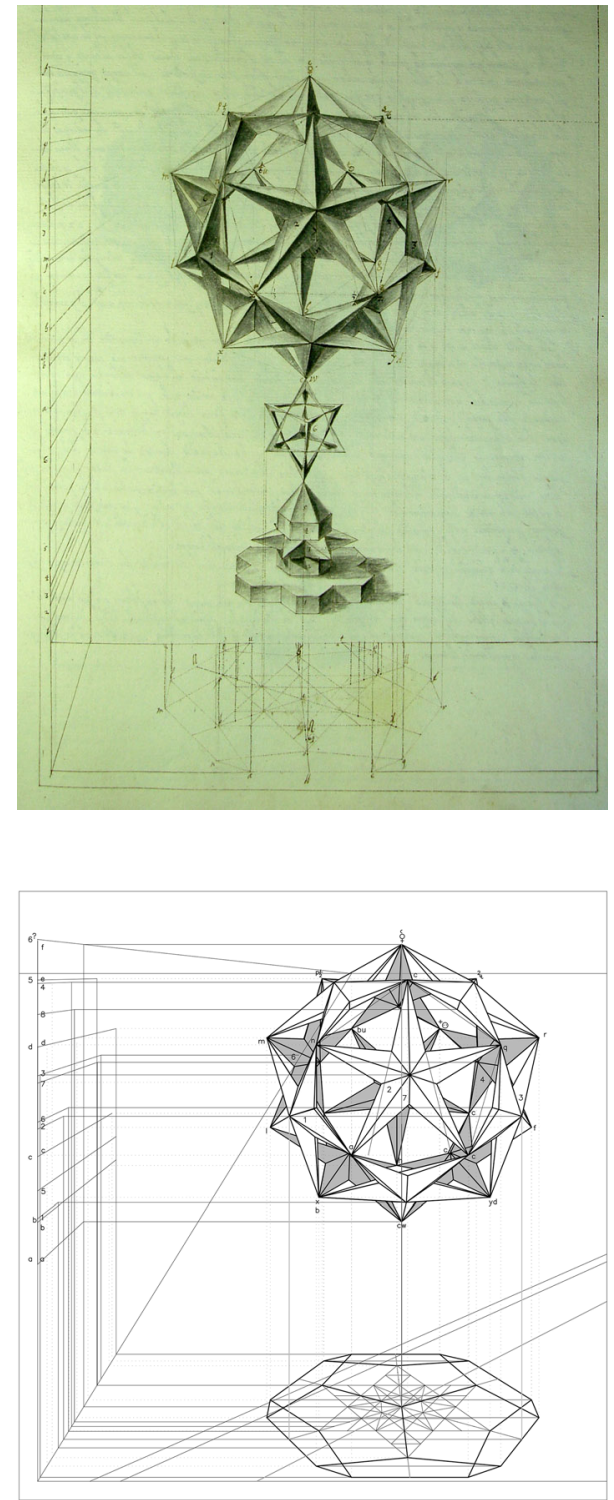

illustrations in the manuscripts with the engravings, it may be observed that the position of the point of view with respect to the object changes greatly (Figs. 13, 14). All these interesting questions are illustrated with a testimony, almost a confession, which is placed in the last chapter of the book: the introduction of certain paper models. 
Fig. 16 Reinterpretation of different star polyhedra constructions by Jamnitzer in the anonymous manuscript (1688: fol. 73r)

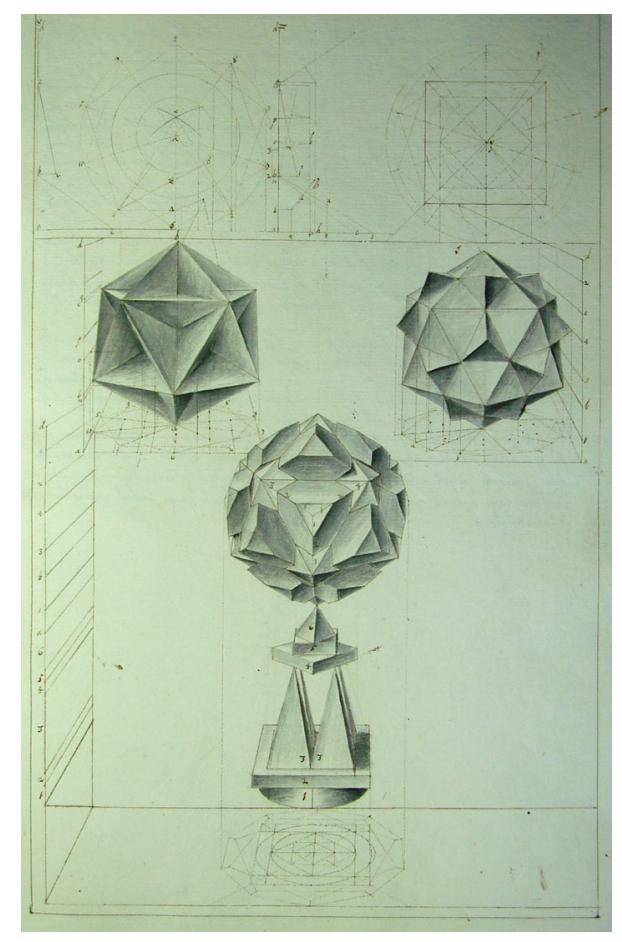

...Through my work and dedication, (...) I have achieved the representation of bodies which I made of paper using geometric rules and precepts with the help of their physical and real constitution. ${ }^{10}$ (Anonymous 1688: fol. 57v).

In constructing these bodies, prior knowledge of the reference model's geometry (the regular polyhedron before variations) would solve the metric problem underlying the operation. The coincidence and validation criterion of the restitution of the complex piece would be determined by trial-and-error, starting from the visual experience of the model generated from the original engraving. Notwithstanding, it appears that moving those scaled objects with respect to a station point would also be undeniably useful when creating each illustration in a similar fashion to (though not exact replicas of) the reference engraving.

This physical modeling approach would run parallel to the geometric codification of the polyhedra internal structure. This is absolutely necessary in order for the figure to be correctly interpreted, described and, finally, put into perspective with all its corpus of auxiliary lines, as the author masterfully accomplishes.

\footnotetext{
${ }^{10}$ Translated from original quotation: “...yo he solicitado a costa de mi trabajo y aplicación, (...) poniendo en práctica la representación de los cuerpos para que me he ayudado de su real y física constitución habiéndolos hecho y formado de papel con la regla y fundamento geométrico" (Anonymous 1688: fol. $57 \mathrm{v})$.
} 
Fig. 17 Graphic transcription elaborated by authors

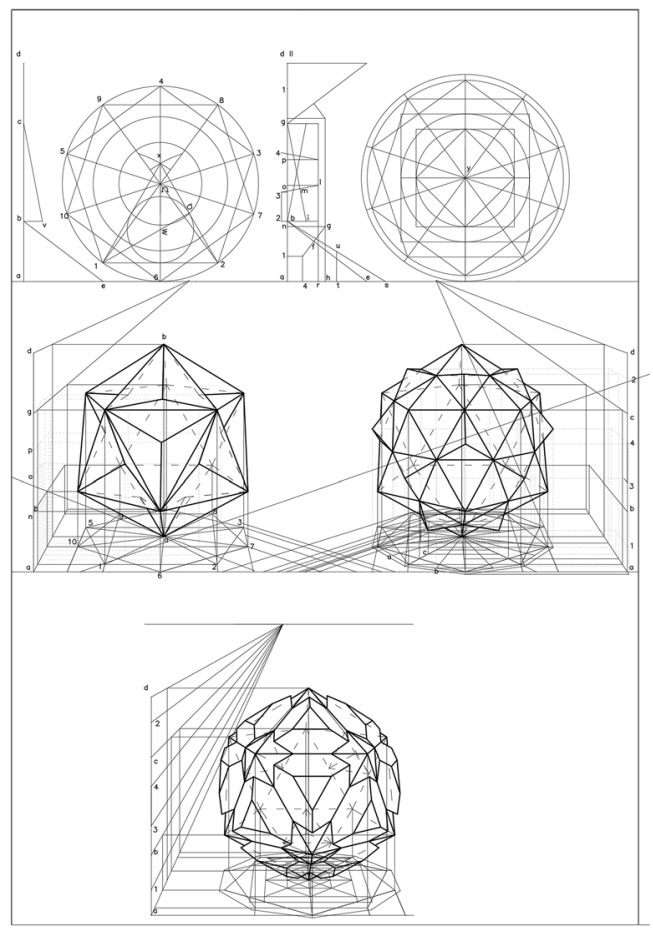

\section{Conclusion}

The study of these three particular cases from three Spanish manuscripts on perspective aims not to provide definitive answers to define the cultural and scientific background of perspective and the systems of architectural representation. Rather, these examples show testimonies of great value regarding the way of understanding perspective in different variations that, in every period and place, have diverged from the canonical trend. The first two cases provide graphic interpretation to unsolved aspects from outside orthodox perspective theory. In the third case a step forward is taken towards the possibility of the perspective restitution of the image.

Hernán Ruiz's manuscript on perspective depicts a scientific sphere in sixteenth century Seville that knew and applied the geometric theory of ancient authors. The practice resulting from Euclid's theorems was considered so prestigious in this circle that it made this Renaissance artist follow them despite the advantages of the more simple postulates of the Italian model proposed by Serlio. The manuscript portrays an interesting case of revision of the angular paradigm in a specific context that led a Renaissance scholar and architect to sketch a particular method of drawing perspective. To follow Euclid's principles in optics was a rather more complex method to accomplish but was not against the artists' cultural beliefs. 
The manuscript by Antonio de Torreblanca, on the contrary, is a fine example of a perspective treatise and is both well structured and well documented. Notwithstanding, a deeper analysis depicts an artist that, as a good artisan, truly understands the art by means of experience and ingenuity, and is therefore capable of presenting a novel proposal. In his own words: "to my knowledge, no one has studied [this subject] or written it yet. Maybe it could be possible to find other instances, though expressed differently, as the present work is the result of my effort only." (Torreblanca 1616-1617: fols. 59-59v). This study also revealed the survival of archaic formulae of perspective projections in the circle of artisans surrounding Torreblanca even in the seventeenth century. In this case the formulae were for bifocalism but this also happened with the angular perspective by Hernán Ruiz, which was still being mentioned by Simón García in 1681.

Finally, the fourth book of the anonymous treatise Artes Exçelençias dela Perspectiba, portrays the first case of 'graphic hermeneutics' in the history of Spain. This entire book focuses on the study and reinterpretation-exclusively from the graphic point of view-of the mysterious illustrations compiled in "Perspectiva Corporium Regularium" by Jamnitzer (1568).

To some extent, though largely unexplored, the ancient, heterodox reminiscences displayed here must somehow perdure in other European spheres and would prove an interesting field of research for scholars.

\section{References}

AA.VV. 1998. Libro de Arquitectura. Hernán Ruiz II, eds. Alfonso Jiménez Martín et al., Sevilla: Fundación Sevillana de Electricidad.

Anonymous. 1688. Artes Exçelençias dela Perspectiba a maestro P. Gómez de Alcuña, 1688. Biblioteca de la Fundación Casa de Medina Sidonia. Ms. 3130.

Barbaro, Daniele. 1569. La pratica della perspettiva di monsignor Daniel Barbaro .... opera molto utile a pittori, a scultori \& ad architetti. Venecia: Appresso Camillo \& Rutilio Borgominieri Fratelli.

Burbon del Monte, Guidobaldo. 1600. Perspectiva libri sex. Pesaro: Hieronymum Concordiam.

Burucúa, José Emilio. 1989-1990-1991. Arte difícil y esquiva. Uso y significado de la perspectiva en España, Portugal y las colonias iberoamericanas, siglos XVI-XVIII. Cuadernos de Historia de España. Buenos Aires: Instituto de Historia de España. LXXI (1990): 131-186. LXXII (1990): 179-280. LXXIII (1991): 174-290.

Cabezas-Gelabert, Lino. 1984. Tratadistas y tratados españoles de perspectiva desde sus orígenes hasta la geometría descriptiva de Gaspard Monge 1526-1803. PhD. thesis, Universidad de Barcelona.

Carduchi, Luis. c. 1650. Tratado Geométrico, Biblioteca Nacional del Perú, Ms. F97.

Chastel A. and R Klein. 1989. Introducción, notas y apéndices. In: Pomponio Gaurico. Sobre la escultura (1504). Madrid: Akal.

Desargues, Girard (and Abraham Bosse). 1648. La maniere universelle de M. Desargues pour practiquer la perspective. París: Pierre des Hayes.

Dubreuil, Jean. 1642. La perspective pratique nécessaire à tous peintres, graveurs, sculpteurs... París: Melchor Tavernier. (second part 1647 and third part 1649).

Gaurico, Pomponio. 1504. Sobre la Escultura, eds. André Chastel and Robert Klein. Madrid: Akal, 1989.

Gentil Baldrich, José María. 1998. El libro de perspectiva. In: Hernán Ruiz, Libro De Arquitectura, vol. 2, pp. 215-234. Sevilla: Fundacion Sevillana de Electricidad.

Gentil Baldrich, José María. 2012a. News Upon the Anonymous Manuscript 'Artes Exçelençias de la perspectiba': Short Chronicle of a Publication. EGA, 19: 48-49. 
Gentil Baldrich, José María. 2012b. Sobre la supuesta perspectiva antigua y algunas consecuencias modernas. Sevilla: IAUCC.

Gentil Baldrich, J.M. and Martín-Pastor, A. 2006. In Praise of Erudition and the Reinstatement of Memory. The Mysterious Case of Gómez de Alcuña or the Manuscript Found in Sanlúcar. In: Otros Textos, XI Expresión Gráfica Arquitectónica Conference Proceeding, 251-272.

Gentil Baldrich, J.M. and Martín-Pastor, A. 2015. Poliedra as Form of Geometric Knowledge: The Spanish Jamnitzer or the Fourth Book of 'Artes Exçelençias dela Perspectiba'. EGA 25: 56-65.

Goiti, Felipe Lázaro de. 1643. Primera Parte Del Prinçipio, Yfundamento De la perspectiva... Biblioteca Nacional de España. Ms. 12830.

González-Román, Carmen. 2007. 'Los siete tratados de la perespectiva practica'. La primera versión del libro de Antonio de Torreblanca. Academia 102-103: 33-60.

Herrera, Juan. 1584. Institución de la Academia Real de Matemáticas. Facsimile rpt. in: Institución ..., eds. José Simón Díaz and Luis Cervera Vera. Madrid: Instituto de Estudios Madrileños, 1995.

Hondius, Henry. 1625. Introduction en la science de perspective. La Haya.

Jamnitzer, Wentzel. 1568. Perspectiva Corporum Regularium [...] Darvon Plato in Timoe und Euclidis... Nuremberg.

Marolois, Samuel. 1633. Opticae sive perspectivae, pars prima. Ámsterdam. In: Geometria theorica et practica, optica, perspectiva... Ámsterdam, 1638

Martín-Pastor, Andrés. 2009. Artes Exçelençias de la Perspectiba, a maestro P. Gómez de Alcuña, 1688. PhD. thesis, Universidad de Sevilla.

Martín-Pastor, A. and Granado-Castro, G. 2015. Contribution to the Study of Instruction in Geometry and Architectural Representation in Spain during the Seventeenth Century. Nexus Network Journal, 17: 231-251.

Martín-Pastor, A; Beltrán Corbalán, D; and Marsilla de Pascual, F. 2010. Artes Exçelençias de la Perspectiba. Murcia: Ediciones Tres Fronteras. [Vol 1. Facsimile; Vol 2. Studies and transcription].

Monge, Gaspard. 1797. Géométrie descriptive. Paris: Gabay.

Muñoz, Salvador. 1642. Las dos reglas de la perspectiva práctica de Iacome Barozzi de Viñola, traducidas y comentadas por... Biblioteca Nacional de España, Ms. 11323.

Navarro de Zuvillaga, Javier. 1989. Los dos libros de Geometría y perspectiva práctica de Antonio de Torreblanca, Academia 69: 451-488.

Navascués Palacio, Pedro. 1974. Libro de Arquitectura. Madrid, Escuela Técnica Superior de Arquitectura de Madrid.

Niceron, Jean-François. 1646. Thaumaturgus opticus sev admiranda optice, catoptrices, dioptrices, pars prima. París: François Langlois.

Ondériz, Pedro Ambrosio. 1585. La Perspectiva y Especularia de Euclides. Traduzidas en vulgar castellano y dirigidas a la S. C. R. M. del Rey don Phelippe nuestro Señor. Por Pedro su criado. Madrid: Alonso Gómez.

Panofsky, Erwin. 1927. Die Perspektive als 'Symbolische Form', Vorträge der Bibliotek Wasburg (1924-1925). [Spanish trad. La perspectiva como forma simbólica. Barcelona: Fábula-Tusquet, 2003].

Ricci de Guevara, Juan Andrés. c.1659. La pintura sabia. Library of Fundación Lázaro Galdiano, M31/13 Ms. 265.1 ${ }^{\mathrm{a}}$ Facsimile rpt. in: Vida y obra de Fray Juan Ricci, eds. Elías Tormo, and Enrique Lafuente Ferrari, Madrid, 1930; $2^{\text {a }}$ Facsimile rpt. in: La pintura sabia. Fray Juan Andrés Ricci, eds. Fernando Marías, and Felipe Pereda, Toledo: Pareja Editor, 2002.

Rojas Sarmiento, Juan de. 1551. Commentariorum in astrolabium, quod planisphaerium vocant, libri sex. París.

Ruiz II El Joven [the Younger], Hernán. c.1560. Libro de Arquitectura. Library of ETSA, Universidad Politécnica de Madrid, Ms. Sig.-R-39. $1^{\text {a }}$ Facsimile rpt. and studies in: Libro de Arquitectura, ed. Pedro Navascués Palacio, Madrid: ETSA, 1974. $2^{\circ}$ facsimile rpt. and studies in: Libro de Arquitectura. Hernán Ruiz II, eds. Alfonso Jiménez Martín et alt., Sevilla: Fundación Sevillana de Electricidad, 1998.

San Miguel, Fray Andrés de. Obras. c.1652. Benson Latin American Collection, General Libraries, The University of Texas at Austin, Ms. 31775792. Facsimile rpt. in: Obras de fray Andrés de San Miguel, eds. Francisco De la Maza, and Eduardo Báez Macías, Mexico City: UNAM, 1969.

Serlio, Sebastiano. 1545. Il primo libro d'Architectura...Il secondo libro di perspectiva di Sebastiano Serlio, París: De Iehan Barbé.

García, Simón. 1681. Compendio de architectura y simetría de los templos, conforme a la medida del cuerpo humano con algunas demostraciones de geometría... Biblioteca Nacional de España, Ms. 
8884. Facsimile rpt. in: García, Simón, Compendio de architectura y simetría de los templos..., eds. Antonio Bonet Correa, and Carlos Chafón Olmos, Valladolid: Colegio Oficial de Arquitectos de Valladolid, 1991.

Sirigatti, Lorenzo. 1596. La Prattica della Prospettiva del Cavaliere Lorenzo Sirigatti. Venecia: Girolamo Franceschi Sanese.

Torreblanca, Antonio de. c.1600. Los siete Tratados de la perespectiva pratica con el primero de los principios de la geometría y otras Reglas así curiosas como necesarias y provechosas/Util a la Arquitectura y escultura y en particular a la Pintura/Por Antonio de to Reblanca ensamblador Natural de la ciudad de Villena... Biblioteca Nacional Argentina, FD 680 Ms. R806.

Torreblanca, Antonio de. 1616-1617. Los dos libros de geometria y perespectiva pratica. Library of Real Academia de BB. AA. de San Fernando, Ms. 364/3.

Viator, Jean Pèlerin. 1505. De Artificiali Perspectiva. Toul: Pierre Jacques.

Vignola, Iacobo Barrocci and Egnatio Danti. 1583. Le due regole della prospettiva pratica di M. Iacomo Barozzi da Vignola con i comentaris del R.P.M. Egnatio Dante dell ordine de Predicatori. Mathematico dello Studio di Bologna. Roma: Francesco Zannetti.

Zamorano, Rodrigo. 1576. Los seis libros primeros de la geometría de Euclides. Traduzidos en lengua Española por Rodrigo Çamorano Astrólogo y Mathemático, y cathedrático de Cosmographia. Sevilla: Alonso de la Barrera.

José María Gentil Baldrich was professor of 'Descriptive Geometrý at E.T.S. ARQUITECTURA in Universidad Politécnica Madrid between 1984 and 1986. Currently, he is professor of 'Architectural Graphic Expression' at the Universidad de Sevilla. He has published several books: "Traza y modelo en el Renacimiento" (Sevilla, 1998), "Método y aplicación de representación acotada y del terreno" (Madrid, 1998), "Sobre la supuesta perspectiva antigua y algunas consecuencias modernas" (Sevilla, 2011), etc. He has participated in numerous collective works, including more recent: "Sobre la vision y la representación en las culturas del mundo antiguo" (Granada, 2013), "Perspectiva cónica e ideología en el arte" (Madrid, 2014), "Sulla rappresentazione nella antichita: La visione della circonfereza e della sfera" (Rome, 2014) and "Arquitectura y viajes: de la ecfrasis a la fotografía" (Las Palmas, 2014).

Andrés Martín-Pastor holds a degree in Architecture and was awarded a PhD from Universidad de Sevilla (Spain) in 2009. He works as a lecturer in the Department of Graphic Engineering in the same University. His publications focus on the study of Perspective and Geometry in Architecture, making a thorough review from the graphic tradition inherited to new digital tools. In the context of the studies of Systems of Representation, his following works are worthy of note: the facsimile reproduction and studies of the unpublished treatise "Artes Exçelençias dela Perspectiba, 1688", his chapter in book "La puesta en perspectiva en el siglo XVII español" (2014) and his articles "Contribution to the Study of Instruction in Geometry" (2015) and "Poliedra as form of geometric knowledge" (2015). He also has been visiting lecturer at several universities where he has given workshops on Architectural Geometry. His work of developable surfaces in pavilions has been recognised with the Emporia 2015 Silver Award, Innovation in Ephemeral Architecture. 